\title{
Association of Effector Six6 with Vascular Wilt Symptoms Caused by Fusarium oxysporum on Soybean
}

\author{
Alessandra Lanubile, Margaret L. Ellis, Adriano Marocco, and Gary P. Munkvold
}

First and third authors: Department of Sustainable Crop Production, Università Cattolica del Sacro Cuore, 29122 Piacenza, Italy; first and fourth authors: Department of Plant Pathology and Microbiology, Iowa State University, Ames 50011; and second author: Department of Plant Science, California State University, Fresno 93740.

Accepted for publication 24 May 2016.

\begin{abstract}
Lanubile, A., Ellis, M. L., Marocco, A., and Munkvold, G. P. 2016. Association of effector Six6 with vascular wilt symptoms caused by Fusarium oxysporum on soybean. Phytopathology 106:1404-1412.

The Fusarium oxysporum species complex (FOSC) is a widely distributed group of fungi that includes both pathogenic and nonpathogenic isolates. In a previous study, isolates within the FOSC collected primarily from soybean were assessed for the presence of 12 fungal effector genes. Although none of the assayed genes was significantly associated with wilt symptoms on soybean, the secreted in xylem 6 (Six6) gene was present only in three isolates, which all produced high levels of vascular wilt on soybean. In the current study, a collection of $F$. oxysporum isolates from soybean

roots and F. oxysporum f. sp. phaseoli isolates from common bean was screened for the presence of the Six6 gene. Interestingly, all isolates for which the Six 6 amplicon was generated caused wilt symptoms on soybean, and two-thirds of the isolates showed high levels of aggressiveness, indicating a positive association between the presence of the effector gene Six6 and induction of wilt symptoms. The expression profile of the Six6 gene analyzed by quantitative reverse-transcription polymerase chain reaction revealed an enhanced expression for the isolates that caused more severe wilt symptoms on soybean, as established by the greenhouse assay. These findings suggest the suitability of the Six 6 gene as a possible locus for pathogenicity-based molecular diagnostics across the various formae speciales.
\end{abstract}

Fusarium oxysporum Schltdl. is a soilborne fungal species present worldwide that includes both plant-pathogenic and nonpathogenic strains. The pathogenic strains are devastating plant pathogens causing wilt and root rot diseases across a wide array of hosts, including economically important crops such as cotton, tomato, banana, and several legumes such as soybean and common bean (Michielse and Rep 2009). Phytopathogenic strains of $F$. oxysporum have been subdivided into over 100 different host-specific forms (formae speciales), making the $F$. oxysporum species complex (FOSC) a very appealing system to study the relationships between pathogenicity and host specificity (Baayen et al. 2000; Di Pietro et al. 2003; Lievens et al. 2008).

F. oxysporum is one of the most prevalent Fusarium spp. associated with soybean root rot and seedling diseases in Iowa and other soybean-producing regions in North America (Díaz Arias et al. 2013a,b; Killebrew et al. 1993; Rizvi and Yang 1996). In a recent work, the phenotypic and genotypic diversity was explored within the FOSC collected from soybean roots, based on phylogenetic analyses of conserved genes such as the translation elongation factor $1-\alpha(t e f 1 \alpha)$ gene and the mitochondrial small subunit (mtSSU) (Ellis et al. 2014). The results indicated that the tested isolates were polyphyletic in origin, belonging to five clades within the FOSC, including $F$. commune, previously within the FOSC (Skovgaard et al. 2001). Isolate aggressiveness varied within and among clades, with only a weak association between clade and low aggressiveness for one clade (Ellis et al. 2014).

$F$. oxysporum f. sp. phaseoli infects some species of the genus Phaseolus, mainly Phaseolus vulgaris and P. coccineus (de Vega-Bartol

Corresponding author: G. Munkvold; E-mail address: munkvold@iastate.edu

*The $\boldsymbol{e}$-Xtra logo stands for "electronic extra" and indicates that four supplementary figures are published online.

http://dx.doi.org/10.1094/PHYTO-03-16-0118-R

(C) 2016 The American Phytopathological Society et al. 2011), and is one of the principal pathogens limiting dry bean production worldwide. The Fusarium transcription factor $(f t f 1)$ has been identified as being associated with highly virulent $F$. oxysporum f. sp. phaseoli strains toward common bean (de Sousa et al. 2015; Ramos et al. 2007). A rapid and accurate real-time polymerase chain reaction (PCR) assay has been developed to detect highly virulent F. oxysporum f. sp. phaseoli isolates from common bean seed using primers based on the $f t f 1$ (de Sousa et al. 2015).

The identification of pathogenic $F$. oxysporum isolates is traditionally based on pathogenicity testing, which is time consuming and laborious. Ideally, it would be possible to distinguish formae speciales based on DNA sequences directly related to host-specific pathogenicity or nonpathogenicity (Lievens et al. 2008). Unfortunately, molecular discrimination among $F$. oxysporum isolates is seriously complicated by the polyphyletic nature within the FOSC on different hosts, including soybean (Gordon and Martyn 1997; Lievens et al. 2008).

Effectors are typically pathogen proteins and small molecules that promote host colonization (virulence factors or toxins) or modulate plant immunity (avirulence factors and elicitors) or both (Dodds and Rathjen 2010; Hogenhout et al. 2009). Fungal effector genes fall into several classes, including genes coding infection structures, cuticle- and cell-wall-degrading enzymes, fungal toxins, signal cascade components, and suppression of plant immunity (Hogenhout et al. 2009; Houterman et al. 2007; Idnurm and Howlett 2001; Lanubile et al. 2015). Additional fungal effector genes were identified from xylem sap of infected plants, encompassing the "secreted in xylem" (SIX) proteins. Currently, 14 Six genes have been identified in F. oxysporum f. sp. lycopersici, some of which have been successfully used to differentiate between three races of F. oxysporum f. sp. lycopersici (Houterman et al. 2008; Lievens et al. 2009; Rep et al. 2004; Schmidt et al. 2013). The biological function of SIX proteins remains largely unknown and their amino acid sequences display little or no homology with other known proteins. However, for SIX1, SIX3, and SIX4 proteins in F. oxysporum f. sp. lycopersici, interactions with host resistance $(R)$ genes have been 
demonstrated in tomato. Recently, Six6 was shown to contribute to pathogenicity of $F$. oxysporum f. sp. lycopersici and it specifically suppresses I-2-mediated cell death upon transient expression in Nicotiana benthamiana (Gawehns et al. 2014). Most of the Six genes are localized on chromosome 14 of $F$. oxysporum f. sp. lycopersici, including Six6, and, consequently, it is referred to as a "pathogenicity" chromosome (Ma et al. 2010; Schmidt et al. 2013).

The Six genes have been detected in formae speciales other than F. oxysporum f. sp. lycopersici. Lievens et al. (2009) showed that the Six 6 and Six 7 effectors, identified originally in isolates collected from tomato, were present in many other formae speciales, suggesting that they may play a more general role in pathogenicity. The work from Chakrabarti et al. (2011) suggests that the Six6 effector might be used as a diagnostic marker for populations of F. oxysporum from cotton in Australia. They also suggested that a homolog of the $f t f 1$ transcription factor, identified from common bean isolates, might be linked with the Six 6 effector from the cotton isolates. However, this marker was not useful for populations of F. oxysporum in other countries.

In our previous study, 80 isolates collected primarily from soybean were assessed for the presence of 12 fungal effector genes: Fmk1, Fow1, Pda1, PelA, PelD, Pep1, Prt1, Rho1, Sge1, Six1, Six6, and $S n f 1$ (Ellis et al. 2016). Fungal effector genes Fmk1, Fow1, PelA, Rho1, Sge1, and Snf1 were present in all isolates screened, while Pda 1, PelD, Pep1, Prt1, Six 1, and Six6 were dispersed among isolates. Of these, Fmk1, Fow1, Pda1, PelA, Rho1, Sge1, and Snf1 corresponded to previously designated clades based on tef $1 \alpha$ and $\mathrm{mtSSU}$ sequences (Ellis et al. 2014, 2016). The same isolates were also tested in the greenhouse for their ability to cause wilt symptoms on soybean. From the analysis of molecular variance, there was no significant association between any of the assayed genes and wilt symptoms (Ellis et al. 2016). However, the Six6 gene was only present in three previously known wilt isolates from soybean, common bean, and tomato, all of which produced high levels of vascular wilt on soybean in our study.

The objectives of this study were to (i) determine the phylogenetic relationship between $F$. oxysporum isolates from soybean roots and F. oxysporum f. sp. phaseoli isolates from common bean on the basis of the tef $1 \alpha$ and mtSSU loci, (ii) screen isolates for the presence of the fungal effector Six6, and (iii) assess the association between isolate aggressiveness (vascular wilt symptom severity) and the presence and expression level of the Six6 gene.

\section{MATERIALS AND METHODS}

Fungal isolates. In all, 22 isolates of $F$. oxysporum f. sp. phaseoli collected from common bean, 15 isolates of F. oxysporum, and 5 isolates of $F$. commune collected from soybean were used in this study and are listed in Table 1 with their geographical origin. One isolate of F. oxysporum f. sp. lycopersici (FGSC 9935, NRRL34936) collected from tomato, one isolate of $F$. oxysporum f. sp. tracheiphilum (ATCC16608) collected from cowpea, one isolate of $F$. oxysporum f. sp. vasinfectum (CML1098) collected from cotton, one isolate of $F$. oxysporum from coffee (CML755), and one isolate of $F$. oxysporum (FGSC 10445, NRRL54002) that was characterized as a biocontrol were also used in the study and listed in Table 1 . The isolates collected from common bean were previously tested for their pathogenicity toward common bean, as described by de Sousa et al. (2015), whereas the isolates collected from soybean were selected based on their ability to produce vascular wilt symptoms on soybean from a previous study by Ellis et al. (2016) (Table 1). Isolates were maintained on silica in the dark at $5^{\circ} \mathrm{C}$ at the Iowa State University (ISU) Seed Science Center in Ames.

DNA extraction and sequencing. The DNA for each isolate was prepared following the method previously described by Ellis et al. (2014). Briefly, isolates were grown on potato dextrose agar (PDA) for 5 days at $25^{\circ} \mathrm{C}$ with a 12 -h photoperiod. A sterile loop was used to scrape and transfer mycelium and conidia of each isolate to a 250-ml glass flask containing $50 \mathrm{ml}$ of liquid growth media $(3 \mathrm{~g}$ of yeast extract, $3 \mathrm{~g}$ of malt extract, $5 \mathrm{~g}$ of peptone, and $20 \mathrm{~g}$ of dextrose [O'Donnell 1992], plus $2 \mathrm{~g}$ of $\mathrm{NH}_{4} \mathrm{SO}_{4}$ in 1 liter of water). The inoculated medium was placed on an Innova 2100 platform shaker (New Brunswick Scientific Co., Inc., Enfield, CT) at $100 \mathrm{rpm}$ and incubated at ambient temperature for 3 to 5 days. Sterile Miracloth (EMD Biosciences Inc., La Jolla, CA) was used to harvest the mycelium, which was then frozen, lyophilized, and ground in a porcelain mortar and pestle (CoorsTek, Inc., Golden, CO). The fungal DNA was extracted as described by Zelaya-Molina et al. (2011). DNA was evaluated by measuring the concentration and the ratios of absorbance at 260 and $280 \mathrm{~nm}$ (A260/A280) and 260 and $230 \mathrm{~nm}$ (A260/A230) with a NanoDrop ND-1000 spectrophotometer (NanoDrop Technologies, Wilmington, DE), and diluted to $10 \mathrm{ng}$ of genomic DNA using nuclease-free water (Ambion, Austin, TX).

Sequences for tef $1 \alpha$ and $\mathrm{mtSSU}$ for the 15 isolates collected from soybean were previously obtained in the study by Ellis et al. (2014). The tef $1 \alpha$ gene and mtSSU for the remaining 27 isolates from other hosts were amplified using a $25-\mu \mathrm{l}$ PCR mix containing $20 \mathrm{ng}$ of genomic DNA, $5 \mu$ l of $5 \times$ Colorless GoTaq Reaction buffer (Promega Corp., Madison, WI), $2.5 \mu \mathrm{l}$ of $25 \mathrm{mM} \mathrm{MgCl}$ (Promega Corp.), $1.5 \mu \mathrm{l}$ of $1.3 \mathrm{mM}$ each dNTP (Fermentas/Thermo Fisher Scientific, Inc., Pittsburg), $0.5 \mu \mathrm{l}$ of GoTaq Taq polymerase (Promega Corp.), $2.5 \mu$ each of a 5 pmol concentration of primers, and $9.5 \mu \mathrm{l}$ of sterile water. PCR were carried out using a T100 Thermal Cycler (Bio-Rad, Hercules, CA). For amplification of tef $1 \alpha$ and $\mathrm{mtSSU}$, the following primers were used for each gene, respectively: EF-1H (ATGGGTAAGGAAGACAAGAC) and EF2T (GGAAGTACCAGTGATCATGTT) (O’Donnell et al. 1998), and MS1 (CAGCAGTCAAGAATATTAGTCAATG) and MS2 (GCGGATTATCGAATTAAATAAC) (White et al. 1990). The PCR parameters for the tef $1 \alpha$ gene were $94^{\circ} \mathrm{C}$ for $1 \mathrm{~min}$; followed by 35 cycles of a denaturation at $94^{\circ} \mathrm{C}$ for $30 \mathrm{~s}$, annealing at $58^{\circ} \mathrm{C}$ for $45 \mathrm{~s}$, and extension at $72^{\circ} \mathrm{C}$ for $1 \mathrm{~min}$; and a final extension at $72^{\circ} \mathrm{C}$ for $5 \mathrm{~min}$. For the $\mathrm{mtSSU}$, the PCR parameters were $97^{\circ} \mathrm{C}$ for $1 \mathrm{~min}$; followed by 35 cycles of a denaturation at $94^{\circ} \mathrm{C}$ for $35 \mathrm{~s}$, annealing at $52^{\circ} \mathrm{C}$ for $55 \mathrm{~s}$, and extension at $72^{\circ} \mathrm{C}$ for $2 \mathrm{~min}$; and a final extension at $72^{\circ} \mathrm{C}$ for $7 \mathrm{~min}$ (Laurence et al. 2012). All 47 isolates were screened for the presence of the Six6 gene using the same PCR parameters described above. The PCR conditions consisted of an initial denaturing at $94^{\circ} \mathrm{C}$ for $2 \mathrm{~min}$; followed by 32 cycles of $94^{\circ} \mathrm{C}$ for $45 \mathrm{~s}$, annealing at $61^{\circ} \mathrm{C}$ for $45 \mathrm{~s}$, and $72^{\circ} \mathrm{C}$ for $45 \mathrm{~s}$; and a final extension step of $72^{\circ} \mathrm{C}$ for $5 \mathrm{~min}$ (Covey et al. 2014). The primers for amplification of the Six6 gene were Six6F (AGAAGAGTTT GAACCACCGAAGGCG) and Six6R (ACTGGAAATTGTCGCTGC TGAAGTACG) (Covey et al. 2014). Product integrity of the PCR product was analyzed using gel electrophoresis on a $2 \%$ agarose containing 1\% DNA Safe (Applied Biological Materials, Inc., Richmond, BC, Canada). The bands were visualized using the Bio-Rad Gel Doc System and sized using the TriDye 100-bp ladder (New England BioLabs Inc., Ipswich, MA). The PCR product was purified using Exosap-IT (USB Corp., Cleveland), following the manufacturer's protocol.

The purified PCR amplicons were sequenced at the DNA Facility of the ISU Office of Biotechnology in Ames using the ABI 3730x1 DNA Analyzer (Applied Biosystems, Foster City, CA). The raw sequence data for each of the genes was aligned and edited using CodonCode Aligner 3.7.1 (CodonCode Corp, Dedham, MA). The sequences for Six6 gene were compared with known DNA sequences generated by the study by Covey et al. (2014) that were obtained from the National Center for Biotechnology Information (NCBI) database (https://ncbi.nlm.nih.gov).

Phylogenetic analysis. Phylogenies were inferred for tef $1 \alpha$, $\mathrm{mtSSU}$, the combined dataset (sequence data for both the tef $1 \alpha$ and $\mathrm{mtSSU}$ genes), and the effector gene Six6. For the final analyses of $t e f 1 \alpha$ and mtSSU, 54 nucleotide sequences for each gene were used, including representative sequences from six clades within the FOSC, including F. commune, collected from NCBI GenBank from 
studies by O'Donnell et al. (2004) and Ellis et al. (2014). For the analysis of the Six 6 gene, 22 nucleotide sequences were used, including sequences obtained from NCBI GenBank, as reported by Chakrabarti et al. (2011), Covey et al. (2014), and Lievens et al. (2009). Gene sequences obtained from this study were submitted to GenBank with the following accessions: KP681649 to KP681661 for Six6, KP693820 to KP693863 for mtSSU, and KP693864 to KP693907 for tefl $\alpha$. Sequences were aligned using ClustalW
(Thompson et al. 1994). Phylogenetic analyses were performed using the maximum parsimony and maximum-likelihood methods in MEGA 6 (Tamura et al. 2013) and Bayesian inference using the MrBayes plugin of Geneious (Huelsenbeck and Ronquist 2001). For the maximum parsimony analyses, heuristic searches for the most parsimonious trees were conducted with 10 random addition replicates and tree-bisection-reconstruction (Nei and Kumar 2000) with search level 1. The best-fit model of nucleotide substitution for

TABLE 1. Characteristics of isolates in the Fusarium oxysporum species complex evaluated in this study

\begin{tabular}{|c|c|c|c|c|c|c|c|c|c|c|c|c|c|}
\hline Species & Isolate & Host & Origin $^{a}$ & Clade & tef $1 \alpha^{\mathrm{b}}$ & Six6 & $f t f 1^{\mathrm{c}}$ & $N^{\mathrm{d}}$ & Score ${ }^{\mathrm{e}}$ & $\mathrm{Wt}(\mathrm{g})^{\mathrm{f}}$ & Stem ${ }^{g}$ & $\operatorname{Root}^{\mathrm{g}}$ & Agrv $^{h}$ \\
\hline \multicolumn{14}{|l|}{ F. oxysporum } \\
\hline f. sp. phaseoli & 9455 & $\begin{array}{l}\text { Phaseolus } \\
\text { vulgaris }\end{array}$ & Brazil & 3 & $3 B$ & + & + & 3 & 1.5 & 5.98 & 0 & 4 & $\mathrm{~L}$ \\
\hline f. sp. phaseoli & 9840 & P. vulgaris & Brazil & 2 & $2 \mathrm{~A}$ & - & - & 0 & 1 & 6.98 & 0 & 0 & NP \\
\hline f. sp. phaseoli & $2556-1$ & P. vulgaris & Brazil & 3 & $3 \mathrm{E}$ & - & + & 0 & 1 & 6.67 & 0 & 0 & NP \\
\hline f. sp. phaseoli & ATCC 18131 & P. vulgaris & California & 3 & 3B & + & + & 10 & $1.5-4(2.45 \pm 0.24)$ & 2.84 & 10 & 10 & $\mathrm{H}$ \\
\hline f. sp. phaseoli & CML144 & P. vulgaris & Brazil & 2 & $2 \mathrm{~A}$ & - & - & 3 & $1.5-2(1.66 \pm 0.14)$ & 7.15 & 0 & 0 & NP \\
\hline f. sp. phaseoli & FOP16 & P. vulgaris & Colorado & 3 & 3B & + & + & 3 & 1.5 & 5.92 & 0 & 5 & M \\
\hline f. sp. phaseoli & FOP31 & P. vulgaris & Netherlands & 3 & $3 \mathrm{~A}$ & + & + & 10 & $2-5(3.60 \pm 0.23)$ & 2.49 & 10 & 10 & $\mathrm{H}$ \\
\hline f. sp. phaseoli & FOP48 & P. vulgaris & Colorado & 3 & $3 \mathrm{C}$ & - & - & 0 & 1 & 7.38 & 0 & 0 & NP \\
\hline f. sp. phaseoli & FOP52 & P. vulgaris & Colorado & 3 & $3 B$ & + & + & 10 & $2-5(4.50 \pm 0.29)$ & 2.01 & 10 & 10 & $\mathrm{H}$ \\
\hline f. sp. phaseoli & FOP58 & P. vulgaris & Spain & 2 & $2 \mathrm{~F}$ & + & + & 10 & $2-5(3.80 \pm 0.27)$ & 2.64 & 10 & 10 & $\mathrm{H}$ \\
\hline f. sp. phaseoli & FOP8 & P. vulgaris & Colorado & 3 & $3 B$ & + & + & 10 & $2-5(3.65 \pm 0.43)$ & 3.41 & 10 & 10 & $\mathrm{H}$ \\
\hline f. sp. phaseoli & FOPS018 & P. vulgaris & Brazil & 2 & $2 \mathrm{~A}$ & - & + & 0 & 1 & 7.46 & 0 & 0 & NP \\
\hline f. sp. phaseoli & FOPS019 & P. vulgaris & Brazil & 2 & $2 \mathrm{~A}$ & + & + & 1 & 2 & 6.56 & 0 & 5 & M \\
\hline f. sp. phaseoli & FOPS023 & P. vulgaris & Brazil & 2 & $2 \mathrm{~A}$ & + & + & 6 & $1.5-5(2.08 \pm 0.58)$ & 5.94 & 1 & 2 & $\mathrm{~L}$ \\
\hline f. sp. phaseoli & FOPS025 & P. vulgaris & Brazil & 2 & $2 \mathrm{E}$ & + & + & 2 & 1.5 & 6.01 & 1 & 7 & M \\
\hline f. sp. phaseoli & FOPS026 & P. vulgaris & Brazil & 2 & $2 \mathrm{E}$ & + & + & 0 & 1 & 6.29 & 3 & 6 & M \\
\hline f. sp. phaseoli & LAPS152 & P. vulgaris & Brazil & 2 & $2 \mathrm{G}$ & - & + & 0 & 1 & 6.68 & 0 & 0 & NP \\
\hline f. sp. phaseoli & LAPS153 & P. vulgaris & Brazil & 3 & $3 \mathrm{E}$ & - & + & 8 & $1.5-3(1.68 \pm 0.18)$ & 6.05 & 0 & 0 & NP \\
\hline f. sp. phaseoli & LAPS154 & P. vulgaris & Brazil & 3 & $3 \mathrm{E}$ & - & + & 3 & 1.5 & 6.80 & 0 & 0 & NP \\
\hline f. sp. phaseoli & LAPS155 & P. vulgaris & Brazil & 3 & $3 \mathrm{E}$ & - & + & 3 & $1.5-2(1.66 \pm 0.14)$ & 7.52 & 0 & 0 & NP \\
\hline f. sp. phaseoli & LAPS156 & P. vulgaris & Brazil & 3 & $3 \mathrm{E}$ & - & + & 0 & 1 & 5.92 & 0 & 0 & NP \\
\hline f. sp. phaseoli & LAPS157 & P. vulgaris & Brazil & 3 & $3 \mathrm{E}$ & - & - & 0 & 1 & 7.05 & 0 & 0 & NP \\
\hline f. sp. lycopersici & NRRL34936 & $\begin{array}{l}\text { Solanum } \\
\quad \text { lycopersicum }\end{array}$ & Illinois & 3 & $3 \mathrm{~F}$ & + & NA & 0 & 1 & 6.37 & 2 & 4 & M \\
\hline f. sp. tracheiphilum & ATCC16608 & $\begin{array}{l}\text { Vigna } \\
\text { unguiculata }\end{array}$ & Virginia & 2 & $2 \mathrm{D}$ & - & NA & 0 & 1 & 6.75 & 0 & 0 & NP \\
\hline f. sp. vasinfectum & CML1098 & $\begin{array}{l}\text { Gossypium } \\
\text { hirsutum }\end{array}$ & Brazil & 2 & $2 \mathrm{~A}$ & - & - & 2 & 1.5 & 5.85 & 0 & 0 & NP \\
\hline F. oxysporum & CML755 & Coffea arabica & Brazil & 2 & $2 \mathrm{~A}$ & - & - & 0 & 1.5 & 6.82 & 0 & 0 & NP \\
\hline F. oxysporum & NRRL54002 & Soil (biocontrol) & France & 3 & $3 \mathrm{~A}$ & - & NA & 0 & 1 & 6.07 & 0 & 0 & NP \\
\hline F. oxysporum & ATCC62913 & Glycine $\max$ & Georgia & 2 & $2 \mathrm{C}$ & + & NA & 10 & $2-5(3.50 \pm 0.45)$ & 2.27 & 10 & 10 & $\mathrm{H}$ \\
\hline F. oxysporum & FO132 & G. $\max$ & Iowa & 2 & $2 \mathrm{~A}$ & - & NA & 0 & 1 & 7.01 & 0 & 0 & NP \\
\hline F. oxysporum & FO23 & G. $\max$ & Iowa & 5 & $5 \mathrm{~A}$ & - & - & 1 & 1.5 & 6.91 & 0 & 0 & NP \\
\hline F. oxysporum & FO29 & G. $\max$ & Iowa & 3 & $3 \mathrm{D}$ & - & NA & 10 & 1.5 & 5.89 & 1 & 1 & $\mathrm{~L}$ \\
\hline F. oxysporum & FO3 & G. $\max$ & Iowa & 3 & $3 \mathrm{~A}$ & - & - & 1 & 1.5 & 6.89 & 0 & 3 & M \\
\hline F. oxysporum & FO35 & G. $\max$ & Iowa & 5 & $5 \mathrm{~B}$ & - & NA & 6 & 1.5 & 6.39 & 0 & 0 & NP \\
\hline F. oxysporum & FO43 & G. $\max$ & Iowa & 5 & $5 \mathrm{~A}$ & - & NA & 2 & 1.5 & 6.52 & 0 & 0 & NP \\
\hline F. oxysporum & FO5 & G. $\max$ & Iowa & 3 & $3 \mathrm{~A}$ & - & NA & 4 & 1.5 & 6.06 & 0 & 1 & $\mathrm{~L}$ \\
\hline F. oxysporum & FO57 & G. $\max$ & Iowa & 5 & $5 \mathrm{~A}$ & - & NA & 5 & 1.5 & 7.14 & 1 & 2 & $\mathrm{~L}$ \\
\hline F. oxysporum & FO59 & G. $\max$ & Iowa & 3 & $3 \mathrm{D}$ & - & NA & 3 & 1.5 & 7.43 & 0 & 3 & $\mathrm{M}$ \\
\hline F. oxysporum & FO6 & G. $\max$ & Iowa & 2 & $2 \mathrm{~A}$ & - & NA & 6 & 1.5 & 5.80 & 1 & 3 & M \\
\hline F. oxysporum & FO62 & G. $\max$ & Iowa & 5 & $5 \mathrm{~A}$ & - & NA & 3 & $1.5-3(1.68 \pm 0.18)$ & 5.56 & 1 & 3 & M \\
\hline F. oxysporum & FO63 & G. $\max$ & Iowa & 2 & $2 \mathrm{~A}$ & - & - & 2 & 1.5 & 6.31 & 0 & 1 & $\mathrm{~L}$ \\
\hline F. oxysporum & FO79 & G. $\max$ & Iowa & 2 & $2 \mathrm{~B}$ & - & NA & 5 & 1.5 & 6.58 & 1 & 1 & $\mathrm{~L}$ \\
\hline F. oxysporum & NE-5-18sm & G. $\max$ & Nebraska & 3 & $3 \mathrm{D}$ & - & NA & 8 & 1.5 & 6.51 & 0 & 3 & M \\
\hline F. commune & $07-242$ & G. $\max$ & Minnesota & 6 & $6 \mathrm{~A}$ & - & NA & 7 & 1.5 & 6.24 & 2 & 5 & $\mathrm{H}$ \\
\hline F. commune & FO61 & G. $\max$ & Iowa & 6 & $6 \mathrm{~A}$ & - & NA & 6 & 1.5 & 6.91 & 0 & 4 & M \\
\hline F. commune & FO72 & G. $\max$ & Iowa & 6 & $6 \mathrm{~A}$ & - & NA & 7 & 1.5 & 6.58 & 0 & 4 & M \\
\hline F. commune & FO93 & G. $\max$ & Iowa & 6 & $6 \mathrm{~B}$ & - & NA & 6 & $1.5-5(1.68 \pm 0.18)$ & 4.46 & 6 & 9 & $\mathrm{H}$ \\
\hline F. commune & FO117 & G. $\max$ & Iowa & 6 & $6 \mathrm{~A}$ & - & NA & 5 & 1.5 & 7.02 & 5 & 8 & $\mathrm{H}$ \\
\hline$\ldots$ & Control $^{i}$ & $\ldots$ & $\ldots$ & $\ldots$ & $\ldots$ & $\ldots$ & $\ldots$ & 0 & 1 & 8.34 & 0 & 0 & $\ldots$ \\
\hline
\end{tabular}

a Geographic origin.

b Sequence designation for unique tefl $\alpha$ gene sequences; number indicates clade, followed by consecutive letter designations within clades.

c Data from de Sousa et al. (2014) for the Fusarium transcription factor 1 gene (ftfl). NA = data were not collected for these isolates.

d Number out of 10 soybean plants with foliar symptoms.

e Disease score. For the isolates showing a range of disease scores, the average \pm standard error (SE) is indicated after the range values.

f Root weight: average of 10 soybean plants.

g Stem and root lesions: number out of 10 soybean plants with vascular discoloration in the stem and root.

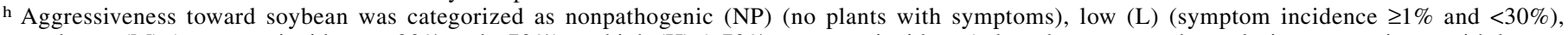
moderate $(\mathrm{M})$ (symptom incidence $\geq 30 \%$ and $<70 \%$ ), or high $(\mathrm{H})$ ( $\geq 70 \%$ symptom incidence), based on stem and root lesion comparisons with known check isolates.

i Noninoculated control. 
each gene and the combined dataset was determined in MEGA 6 for the maximum-likelihood and Bayesian analyses. For the maximum-likelihood analyses, the Kimura two-parameter model (Kimura 1980) plus the $\gamma$ correction for among-site variation $(\mathrm{K} 2+\mathrm{G})$ was used for the tef $1 \alpha$ and Six 6 genes, the Tamura threeparameter model (T92) (Tamura 1992) for the mtSSU, and the T92 model plus the $\gamma$ correction for among-site variation (T92+G) was used for the combined dataset. For the maximum parsimony and maximum-likelihood analyses, gaps were treated as missing data and relative support for branches was estimated with 1,000 bootstrap replications (Felsenstein 1985). For the Bayesian analyses, the likelihood parameter settings (lset), number of substitution types $(\mathrm{nst}=2)$, with a $\gamma$ distribution (rates $=\gamma$ ), and the number of discrete categories used to approximate the $\gamma$ distribution
$($ Ngammacat $=4)$ were selected for all genes and combined dataset. The Bayesian inference trees were constructed using three hot and one cold Markov chain Monte Carlo iterations with $1,100,000$ generations, with sampling every 200 generations, and the first 110,000 generations were discarded as the chains converged.

Greenhouse Fusarium wilt assay. The 47 isolates were tested in the greenhouse for their ability to cause wilt symptoms in soybean, as previously described by Ellis et al. (2016). Greenhouse experiments were established at the ISU Department of Plant Pathology and Microbiology greenhouse facilities in Ames from September to November 2014. Briefly, two soybean seeds of susceptible 'MN1805' (Cruz et al. 2013) were planted in trays with 48 cells containing perlite (Midwest Perlite Co., Appleton, WI). The

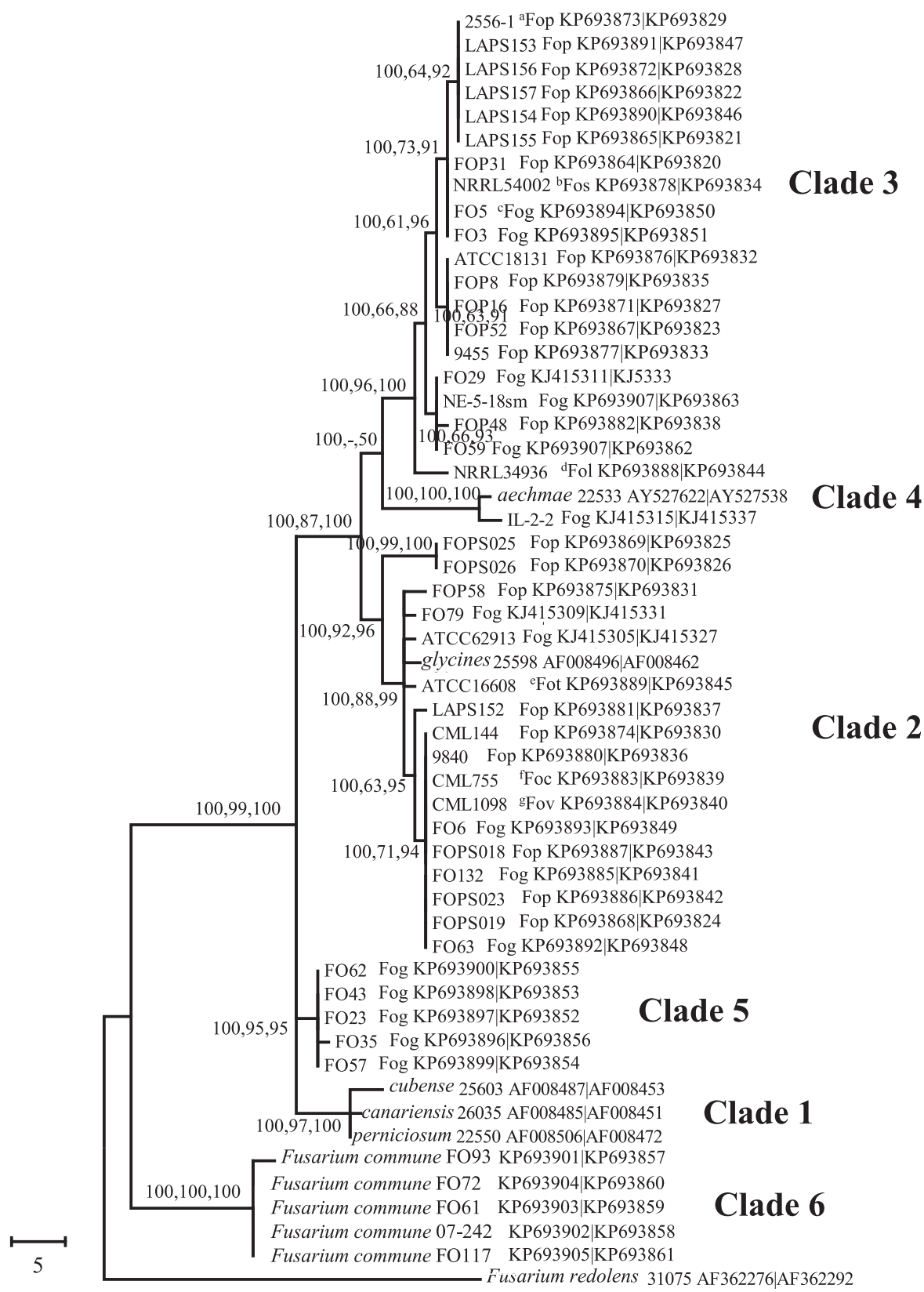

Fig. 1. Maximum parsimony phylogenetic tree of Fusarium oxysporum and F. commune isolates from soybean and common bean inferred from the combined translation elongation factor gene and the mitochondrial small subunit sequence data. All sequences are followed by their GenBank accessions. Bootstrap values for the maximum parsimony and maximum-likelihood analyses (1,000 replications) and Bayesian posterior probabilities are indicated as percentages, in that order, at the internodes. F. redolens strain NRRL31075 was used to root the tree. Fop $=$ F. oxysporum f. sp. phaseoli, Fos $=$ F. oxysporum from soil, Fog $=$ F. oxysporum from Glycine max, $\mathrm{Fol}=$ F. oxysporum f. sp. lycopersici, $\mathrm{Fot}=$ F. oxysporum f. sp. tracheiphilum, Foc $=$ F. oxysporum from Coffea arabica, and Fov $=$ F. oxysporum f. sp. vasinfectum. 
trays were arranged on a greenhouse bench and seedlings were watered two to three times per day. Greenhouse air temperature was maintained at $23 \pm 5^{\circ} \mathrm{C}$. Natural light was supplemented with highpressure sodium grow lights $(400 \mathrm{~W})$ set for a photoperiod of light at $14 \mathrm{~h} \mathrm{day}^{-1}$. Two-week-old seedlings were washed under running tap water, with care taken not to damage roots. The roots were cut with scissors that were sterilized in $10 \%$ commercial bleach, leaving approximately $5 \mathrm{~cm}$ of root length. The remaining roots were then soaked in $30 \mathrm{ml}$ of prepared inoculum for $10 \mathrm{~min}$. To prepare the inoculum, isolates were grown on PDA plates for 5 days in an incubator set at $25^{\circ} \mathrm{C}$. The conidia were dislodged with a pipette tip in $10 \mathrm{ml}$ of sterile water and counted using a hemacytometer. The volume was adjusted by the addition of sterile water to obtain $1 \times 10^{6} \mathrm{conidia} / \mu \mathrm{l}$. Each inoculated plant was transplanted into steamed metro potting mix (Sun Gro Horticulture Canada Ltd., Seba Beach, AB, Canada) in a 237-ml Styrofoam cup. Five plants were inoculated with each isolate. Noninoculated control plants with roots soaked in sterile water were included in the assay. The cups were grouped by isolate into five blocks. Foliar symptoms were scored weekly, starting 2 weeks after transplanting, using an ordinal scale from 1 to 5 , where $1=$ no symptoms and $5=$ severe interveinal chlorosis and necrosis or dead plants (Hartman et al. 1997; Huang and Hartman 1998). The experiment was terminated after 6 weeks. Each plant was carefully removed from the cup and the roots were washed under running tap water. The plants were wrapped in a moist paper towel. Data for fresh root weight were collected. The stems and roots (hypocotyl area) were split longitudinally with an x-acto knife to examine for symptoms of vascular discoloration. Absence or presence of vascular discoloration was recorded for both the roots and stems. The pieces that were symptomatic and the noninoculated controls were cultured on PDA to recover F. oxysporum, if present. Briefly, the pieces of stems and roots were rinsed for $3 \mathrm{~min}$ in $1 \% \mathrm{NaHClO}$ and $3 \mathrm{~min}$ for three times in sterile water. The tissue was blotted on a clean paper towel and placed on the culture medium. The assay for pathogenicity was conducted twice.
Correlations between foliar symptoms (3 weeks after transplanting) and vascular discoloration for stems, roots, and stems and roots combined were estimated using the Kendall $\tau$ b correlation coefficient with PROC CORR of SAS 9.3 (SAS Institute, Inc., Cary, $\mathrm{NC}$ ). Isolate aggressiveness was categorized based on the incidence of vascular discoloration (root and stem symptoms combined) from 10 plants, where high equals $\geq 70 \%$ plants with symptoms, moderate equals $\geq 30 \%$ plants with symptom incidence $<70 \%$, low equals $\geq 1 \%$ plants with symptom incidence $<30 \%$, or nonpathogenic equals no plants with symptoms.

RNA isolation and real-time reverse-transcription PCR expression analysis. Fungal mycelium of the $13 \mathrm{~F}$. oxysporum isolates having the Six6 gene was ground in liquid nitrogen with a mortar and pestle, and total RNA was extracted from $1 \mathrm{~g}$ of sample using the TRIzol protocol (Invitrogen, Carlsbad, CA). RNA was purified with the RNA Clean-up protocol (Qiagen, Valencia, CA), according to the manufacturer's instructions, including the optional on-column DNase digestion, and stored at $-80^{\circ} \mathrm{C}$. The amount and the quality of the total RNA were estimated by measuring the concentration and A260/A280 and A260/A230 ratios with a NanoDrop ND-1000 spectrophotometer (NanoDrop Technologies), as well as by agarose gel electrophoresis. A 1- $\mu \mathrm{g}$ sample of total RNA was used for cDNA synthesis following the iScript cDNA synthesis kit protocol (Bio-Rad). Transcript abundances were identified using a reaction mix containing $12.5 \mu \mathrm{l}$ of $2 \times \mathrm{SYBR}$ Green Mastermix (Applied Biosystems), $0.4 \mu \mathrm{M}$ each primer, and 20 ng of single-strand cDNA template, adding RNase free water to reach the final volume of $25 \mu \mathrm{l}$. All analyses were performed on the CFX-96 device (Bio-Rad), according to the following conditions: $95^{\circ} \mathrm{C}$ for $3 \mathrm{~min}$ and 44 cycles at $95^{\circ} \mathrm{C} 10 \mathrm{~s}$ and $58^{\circ} \mathrm{C} 25 \mathrm{~s}$. A melting curve analysis, ranging from 60 to $95^{\circ} \mathrm{C}$, was used to identify different amplicons, including nonspecific products. Each sample was analyzed in triplicate together with a template-free negative control. Six 6 gene-specific primers were designed within consecutive exons, separated by an intron, using Primer3 software, and their sequences are here reported: Six6F (GGCTGAGCACAC

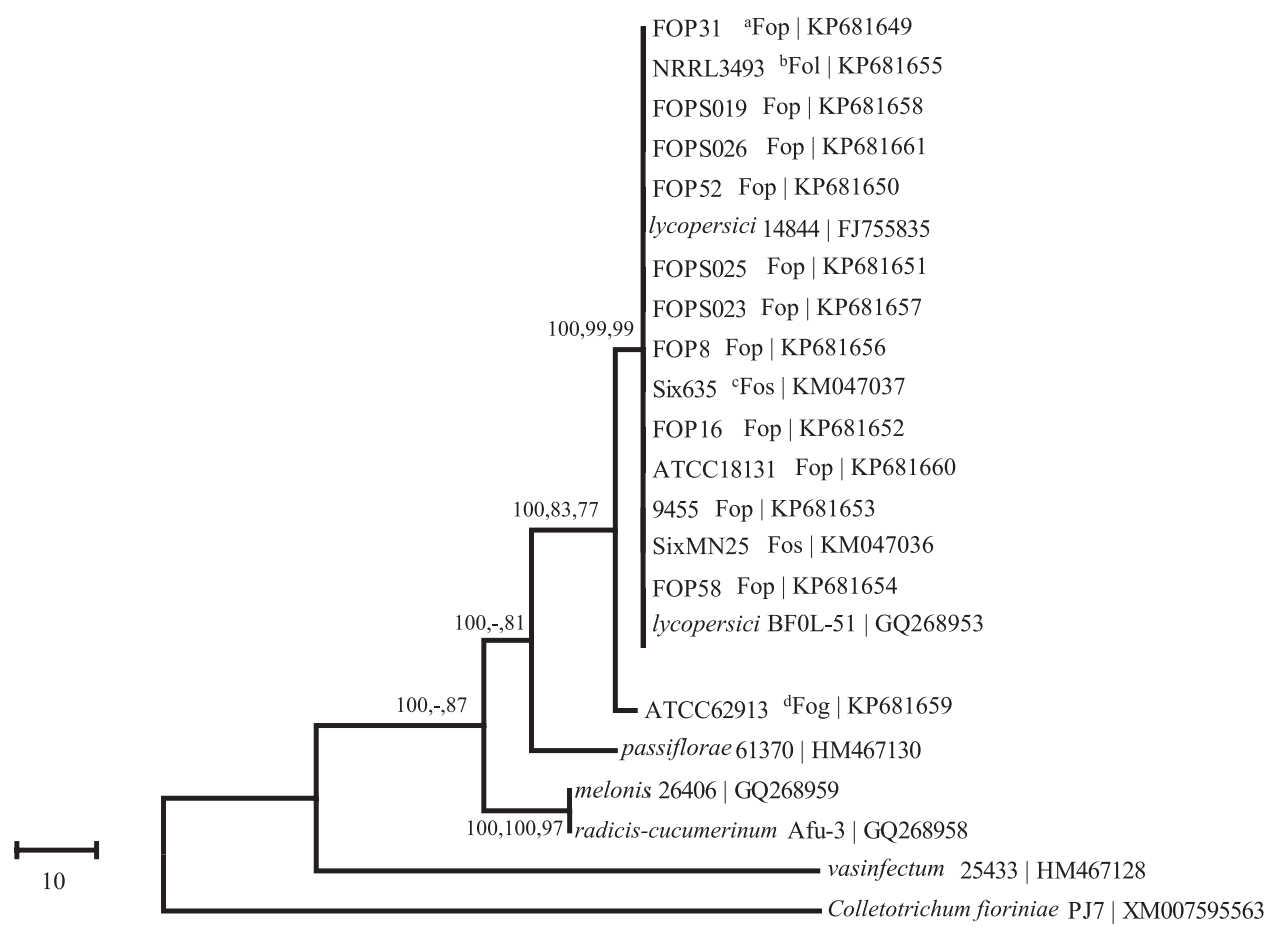

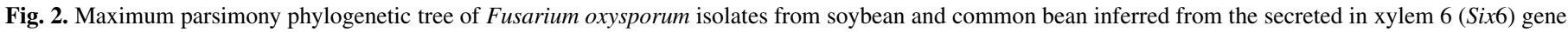

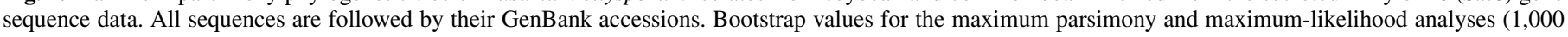

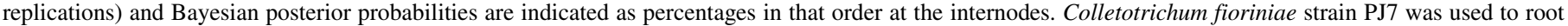
the tree. Fop $=$ F. oxysporum f. sp. phaseoli, Fol = F. oxysporum f. sp. lycopersici, Fos $=$ F. oxysporum from soil, and Fog $=$ F. oxysporum from Glycine max. 
CATCAATT) and Six6R (CTGTACACAAATCTCCCGCG). Relative quantification was normalized to the housekeeping control gene tef $1 \alpha$ (tef $1 \alpha \mathrm{F}$ : GTCACTTGATCTACCAGTGCG; tef $1 \alpha \mathrm{R}$ : GGTGACATAGTAGCGAGGAGT) and fold change (FC) in gene expression was calculated using the $2^{-\Delta \Delta \mathrm{Ct}}$ method (Schmittgen and Livak 2008). This method allows for calculation of the expression ratio of a target gene between a test sample and its relative calibrator (Real-Time PCR Application Guide; Bio-Rad) which, in the present case, corresponded to the different FOSC isolates (test) compared with the isolate $F$. oxysporum f. sp. phaseoli 9455 (calibrator).

\section{RESULTS}

Sequence analysis and phylogeny. Overall, this analysis was carried out on sequences from 47 isolates: 22 of $F$. oxysporum f. sp. phaseoli, 17 of $F$. oxysporum, 5 of $F$. commune, 1 of $F$. oxysporum f. sp. lycopersici (NRRL34936) collected from tomato, 1 of $F$. oxysporum f. sp. tracheiphilum (ATCC16608) collected from cowpea, and 1 of F. oxysporum f. sp. vasinfectum (CML1098) collected from cotton (Table 1). The outcome of the tef $1 \alpha, \mathrm{mtSSU}$, and combined data analyses resulted in a total DNA alignment of 577, 615, and 1,171 positions, while 517, 593, and 1,113 bp were constant and used in the final analysis. Maximum parsimony analysis of tef $1 \alpha$ and $\mathrm{mtSSU}$ resulted in 9 and 10 most parsimonious trees, respectively, where consistency index $(\mathrm{CI})=0.872$ and 0.920 , retention index $(\mathrm{RI})=0.970$ and 0.990 , and composite index $(\mathrm{COI})=0.894$ and 0.933 , respectively. The strict consensus trees for maximum parsimony for tef $1 \alpha$ and mtSSU are shown in Supplementary Figures S1 and S2. The maximum-likelihood and Bayesian inference gave similar tree topologies for tef $1 \alpha$ and mtSSU when compared with the maximum parsimony analysis. The bootstrap values for the maximum-likelihood analyses and Bayesian posterior probabilities for the Bayesian analyses for tefl $\alpha$ and $\mathrm{mtSSU}$ are reported. As previously described by Ellis et al. (2014), clades 2 and 3 were not clearly resolved in the trees generated from the tefl $\alpha$ gene, and the $F$. oxysporum f. sp. lycopersici isolate NRRL34936 fell between clade 2 and 3, whereas it grouped with the isolates of clade 2 for the mtSSU.

Maximum parsimony analysis of the combined dataset gave 10 most parsimonious trees $(\mathrm{CI}=0.860, \mathrm{RI}=0.973, \mathrm{COI}=0.884)$. The strict consensus tree for maximum parsimony for the combined dataset along with the bootstrap values for the maximum-likelihood analysis and Bayesian posterior probabilities for the Bayesian analysis are reported in Figure 1. No major topological variations were observed among trees derived from maximum parsimony, maximum-likelihood (Supplementary Fig. S3), and Bayesian inference analysis (Supplementary Fig. S4) for the combined data, as well as for tef $1 \alpha$ and mtSSU. $F$. oxysporum isolates fell into clades 2, 3, and 5 and $F$. commune isolates fell into clade 6 , as previously reported by Ellis et al. (2014). F. oxysporum f. sp. phaseoli isolates were distributed between clade $2(41 \%)$ and clade 3 (59\%). Clade 2 also included $F$. oxysporum f. sp. tracheiphilum (ATCC16608) and F. oxysporum f. sp. vasinfectum (CML1098), whereas $F$. oxysporum f. sp. lycopersici grouped in clade 3 (Fig. 1).

In summary, the phylogenetic analysis of tef $1 \alpha$ and mtSSU dataset revealed that all FOSC isolates tested in this study were topologically polyphyletic in origin, confirming the previous finding by Ellis et al. (2014).

The presence of the Six6 gene was tested by PCR assays in all isolates listed in Table 1. A Six 6 amplicon was found to be present in $11 F$. oxysporum f. sp. phaseoli isolates, the F. oxysporum f. sp. lycopersici isolate NRRL34936, and the F. oxysporum isolate ATCC62913. Sequences of Six6 were determined from all isolates with the gene present. The DNA alignment resulted in 476 positions, while $468 \mathrm{bp}$ were constant and used in the final analysis. The maximum parsimony analysis resulted in 10 most parsimonious trees $(\mathrm{CI}=0.791, \mathrm{RI}=0.823, \mathrm{COI}=0.770)$. The strict consensus tree for maximum parsimony for Six6 along with the bootstrap values for the maximum-likelihood analysis and Bayesian posterior probabilities for the Bayesian analysis are reported in Figure 2. Interestingly, high bootstrap values and Bayesian posterior probabilities support
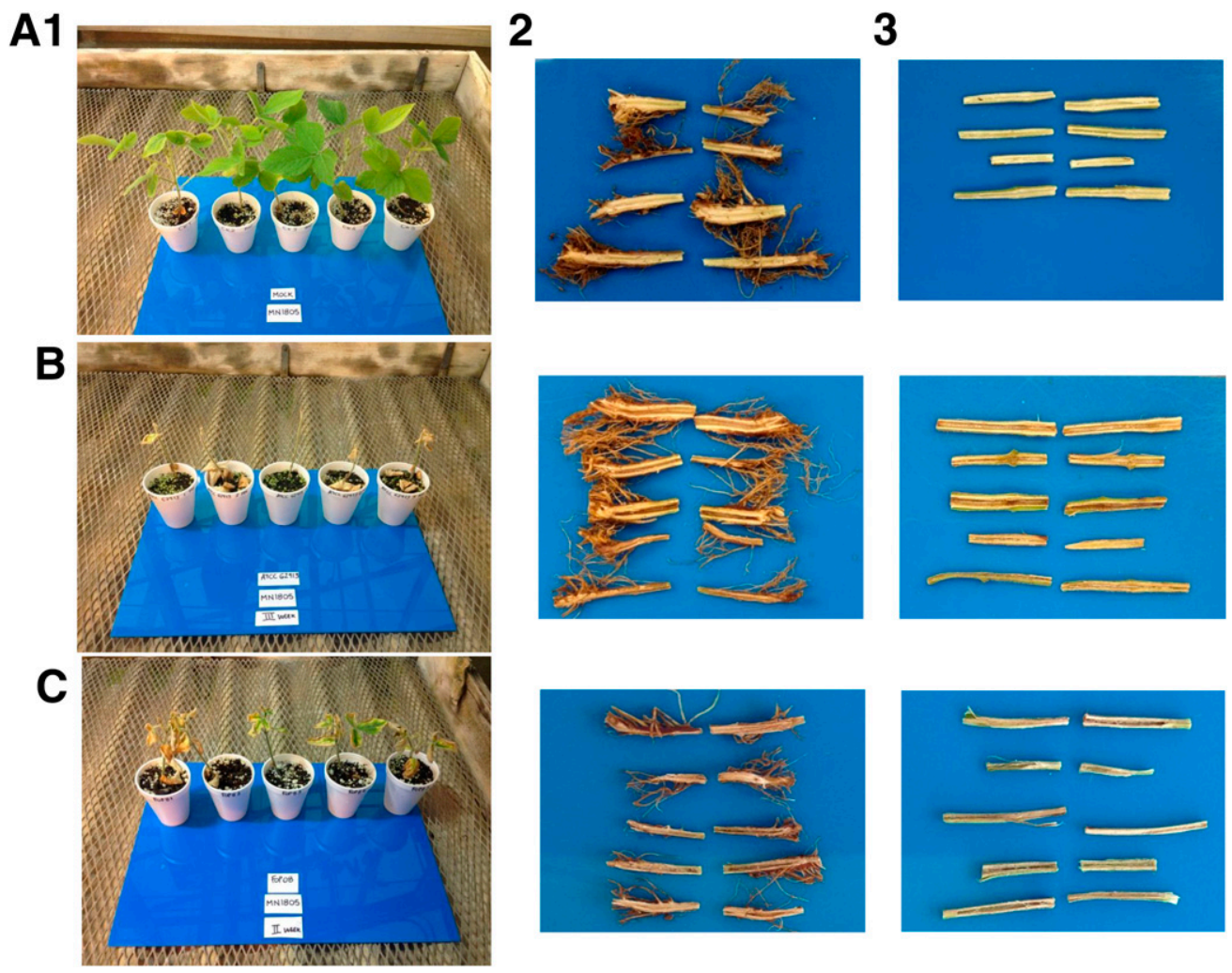

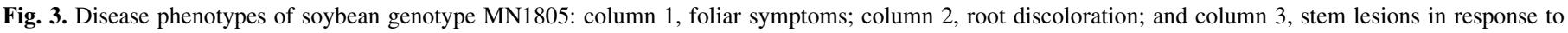
Fusarium wilt. A, Mock-inoculated; B, ATCC62913-inoculated; and C, FOP8-inoculated. 
the monophyly of $F$. oxysporum f. sp. phaseoli and lycopersici isolates. Sequencing of Six6 amplicons revealed that they were identical within $F$. oxysporum f. sp. phaseoli and lycopersici but, notably, a divergence of $F$. oxysporum ATCC62913 was observed in Six6 gene phylogeny. The gene was not present in isolates belonging to clades 4,5 , and 6 but the isolates in clades 2 and 3 were not clearly resolved by clade for the Six6 gene (Table 1; Fig. 2 ). The amplification of the Six6 gene in F. oxysporum f. sp. lycopersici NRLL34936, F. oxysporum f. sp. phaseoli 58, and $F$. oxysporum ATCC62913 isolates confirmed results previously obtained by Ellis et al. (2016). The three isolates are known to cause wilt to their respective hosts and also soybean (Ellis et al. 2016), thus suggesting a possible role of the Six6 gene with pathogenicity toward soybean.

Fusarium wilt assay. In order to assess the link between the presence of the Six6 effector gene and wilt capability of F. oxysporum isolates, inoculations using the susceptible soybean cultivar MN1805 were conducted with all $F$. oxysporum isolates used in this study. Foliar symptoms were best observed at 2 and 3 weeks after inoculation. The frequency of plants with symptoms and range of severity were the same for 2 and 3 weeks and, thus, are reported together in Table 1 . Of the 47 isolates, 34 were able to infect soybean seedlings and cause foliar symptoms that included plants with symptoms ranging from leaves showing slight yellowing or chlorotic flecks or blotches to intervenal chlorosis and necrosis, or entirely defoliated plants. Control plants did not develop any symptoms (Fig. 3A). Notably, of the 34 isolates causing foliar symptoms, 28 also induced vascular discoloration (Table 1). Conversely, vascular discoloration in the stem and root but not foliar symptoms were observed in seedlings inoculated with two isolates: F. oxysporum f. sp. phaseoli FOPS026 and F. oxysporum f. sp. lycopersici NRRL34936. Both isolates amplified for the Six6 gene. Foliar symptoms correlated moderately to strongly with vascular discoloration, depending on the timing of foliar symptom assessment; 3-week foliar symptoms had the best correlation with vascular discoloration. The correlations between combined root and stem vascular discoloration and 2- or 3-week foliar symptoms were $0.44638(P<0.0001)$ and $0.71064(P<0.0001)$, respectively. Aggressiveness was categorized as high, moderate, or low based on stem and root vascular discoloration comparisons with known check isolates. In all, 9 isolates were ranked as high, 12 as moderate, and 7 as low, while the remaining isolates did not cause wilt symptoms on soybean (Table 1). The isolates with the highest incidence of vascular discoloration (10 of 10 plants with stem and

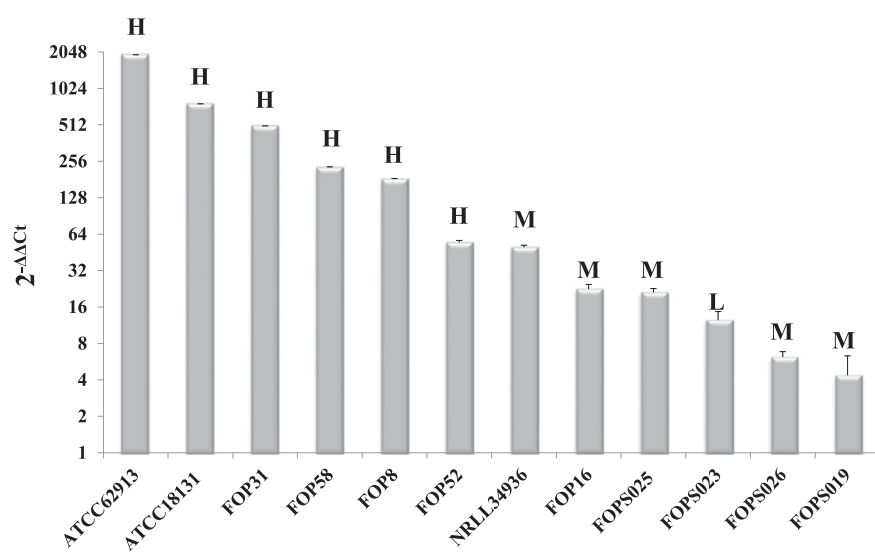

Fig. 4. Expression of Six6 gene assayed by real-time reverse-transcription polymerase chain reaction from different isolates in the Fusarium oxysporum species complex. Relative quantification of Six6 gene cycle threshold $(\mathrm{Ct})$ values was normalized to the housekeeping translation elongation factor $($ tefl $\alpha)$ gene. Values represent the number of times Six6 is expressed by the different F. oxysporum species complex isolates compared with the isolate $F$. oxysporum $\mathrm{f}$. sp. phaseoli 9455. H, M, and L indicate high, medium, and low levels of aggressiveness, respectively, as shown by greenhouse assays. root lesions) and severe foliar symptoms (10 plants with a score ranging from 2 to 5) included FOP31, FOP52, FOP58, FOP8, and F. oxysporum ATCC62913. FOP31, FOP58, and FOP8 were previously reported as highly virulent vascular wilt pathogens in common bean (de Sousa et al. 2015). Foliar symptoms and vascular discoloration in the root and stem elicited by $F$. oxysporum ATCC62913 and FOP8 in soybean genotype MN1805 can be seen in Figure $3 \mathrm{~B}$ and $\mathrm{C}$, respectively.

Most wilt-inducing isolates grouped in clade 3 (approximately $43 \%$ ), followed by clades 2,6 , and 5 , which included 32,18 , and $7 \%$ of isolates, respectively, producing wilt symptoms on soybean (Table 1). Although the Six6 gene was not present in all isolates causing wilt symptoms on soybean, all isolates with a copy of the Six6 amplicon produced wilt symptoms on soybean, and twothirds of these isolates were defined as highly aggressive. These results suggest a positive association between the presence of the effector gene Six6 and capability to cause wilt symptoms in soybean.

Expression analysis of the Six 6 gene. The expression profile of the effector gene Six6 was analyzed by real-time reversetranscription (RT)-PCR. In order to explore the differences among the FOSC isolates that had a copy of the Six6 gene, FC were measured by comparing all positive isolates with the $F$. oxysporum f. sp. phaseoli isolate 9455 (Fig. 4).

The upregulation of Six6 occurred in all tested isolates, with values ranging from $1,943.3$ to 4.4 , with the highest and lowest values for isolates F. oxysporum ATCC62913 (highly aggressive) and FOPS019 (moderately aggressive), respectively. The maximal levels of expression were reached by the isolates that caused more severe wilt symptoms in the greenhouse assay. In addition to the F. oxysporum ATCC62913 isolate, enhanced induction also was observed in F. oxysporum f. sp. phaseoli isolates ATCC18131, FOP31, FOP58, FOP8, and FOP52. The F. oxysporum f. sp. lycopersici isolate NRRL34936, although moderately aggressive as a wilt isolate, showed strong induction up to 50-fold; whereas, in contrast, weaker alterations were measured in the remaining moderately aggressive wilt isolates (Fig. 4).

\section{DISCUSSION}

In this study, genotypic and phenotypic diversity within the FOSC isolates was reported. $F$. oxysporum $\mathrm{f}$. sp. phaseoli isolates collected from common bean and additional $F$. oxysporum isolates collected from soybean were polyphyletic based on tef $1 \alpha$ and $\mathrm{mtSSU}$ phylogeny. These findings confirmed the phylogenetic analysis previously described by Ellis et al. (2014), revealing that isolates within FOSC from soybean were polyphyletic in origin, with soybean isolates belonging to five clades within the FOSC, including $F$. commune. Common bean isolates were distributed among clades 2 and 3 . The phylogenetic divide indicated that formae speciales of $F$. oxysporum, including $F$. oxysporum f. sp. phaseoli, had multiple evolutionary origins, as already stated in other studies using different FOSC in other hosts such as banana (O’Donnell et al. 1998), common bean (Alves-Santos et al. 1999), bulb species (Baayen et al. 2000), cotton (Abo et al. 2005), soil (Laurence et al. 2012), date palm (Laurence et al. 2015), and soybean (Ellis et al. 2014).

Despite being polyphyletic based on tef $1 \alpha$ and mtSSU loci, the putative effector gene Six6 was found to be monophyletic for $F$. oxysporum f. sp. phaseoli and F. oxysporum f. sp. lycopersici isolates belonging to clades 2 and 3 within the FOSC. Nucleotide sequences of the Six6 gene for all $F$. oxysporum f. sp. phaseoli isolates containing a copy of the gene and the $F$. oxysporum f. sp. lycopersici isolate NRRL34936 collected from tomato were identical. F. oxysporum isolate ATCC62913 collected from soybean had a unique nucleotide sequence, with notable divergence in Six6 gene phylogeny. Therefore, for all isolates, with the exception of F. oxysporum ATCC62913, this would suggest that the effector gene 
Six6 has a single origin and that horizontal gene transfer (HGT) explains the presences and absences of the gene within and across clades 2 and 3 of the FOSC (Baayen et al. 2000; Fourie et al. 2011; O'Donnell et al. 1998). With the rapid advances in sequencing technologies, there has been a significant increase in genomic evidence to support the HGT hypothesis of pathogenicity factors in F. oxysporum. Multiple studies reported that the nucleic acid and amino acid sequences of Six genes are highly conserved both within and between formae speciales (Houterman et al. 2008; Rep et al. 2004; Thatcher et al. 2012; Van Der Does et al. 2008). This high degree of sequence conservation is thought to indicate the recent evolutionary origin of Six genes that may have then been horizontally transferred between strains. Ma et al. (2010) investigated lineagespecific regions in F. oxysporum f. sp. lycopersici and whether these regions were acquired by horizontal transfer. The lineage-specific regions in $F$. oxysporum f. sp. lycopersici are enriched for genes related to host-pathogen interactions, including chromosome 14, which is where the Six genes are mostly located (Lievens et al. 2009; Ma et al. 2010; Rep and Kistler 2010). Ma et al. (2010) concluded that the mobility of lineage-specific chromosome 14 between strains explains its presence in tomato wilt pathogens, comprising several clonal lineages polyphyletic within the FOSC, but absence in other lineages (Van Der Does et al. 2008). Furthermore, Ma et al. (2010) also determined that horizontal transfer of host-specificity factors between $F$. oxysporum species may explain the polyphyletic origins of $F$. oxysporum as well as their host specialization.

In order to determine possible correlations between the presence of the Six 6 effector gene and F. oxysporum pathogenicity, the ability to cause wilt symptoms in soybean was assayed in this study. Previously, the $F$. oxysporum isolates collected from soybean were tested in a greenhouse study to determine their ability to produce vascular wilt (Ellis et al. 2016). The three isolates producing high levels of vascular wilt on soybean (ATCC62913, FO93, and FOP58) were also confirmed to be highly aggressive in the current study. In addition, all $F$. oxysporum f. sp. phaseoli isolates that produced symptoms of wilt on soybean were also pathogenic toward common bean, according to de Sousa et al. (2015). In our study, seven F. oxysporum f. sp. phaseoli isolates (2256-1, FOPS018, LAPS152, LAPS153, LAPS154, LAPS155, and LAPS156) did not cause wilt symptoms in soybean. The same seven $F$. oxysporum f. sp. phaseoli isolates are highly virulent wilt pathogens to common bean (de Sousa et al. 2015). Interestingly, these isolates did not amplify for the Six 6 gene but did amplify for the $f t f 1$ transcription factor (de Sousa et al. 2015). Factor $f t f 1$ was previously determined to be highly expressed during infection of common bean by F. oxysporum f. sp. phaseoli in highly aggressive isolates but not in weakly aggressive and nonpathogenic isolates (Ramos et al. 2007). Transcription factor $f t f 1$ is included in a family of related genes in F. oxysporum f. sp. lycopersici, with 3 of the 11 members occurring on pathogenicity chromosome 14 (Ma et al. 2010). The work from Chakrabarti et al. (2011) suggested that a homolog of the ftfl transcription factor, identified from common bean isolates, might be linked with the Six6 effector from populations of $F$. oxysporum cotton isolates in Australia. In the present study, we could not determine a real association between the two genes because, in some cases, $F$. oxysporum f. sp. phaseoli isolates that carried $f t f 1$ gene (de Sousa et al. 2015) did not amplify for the Six6 gene. Furthermore, although all isolates with a copy of Six6 amplicon produced wilt symptoms on soybean, some isolates lacking Six6 were moderately virulent and others with the gene were only weakly virulent, making further analysis of this gene necessary to clarify its diagnostic value.

In our study, the presence of the Six6 gene was also associated with high levels of gene expression, in particular in the F. oxysporum isolates that caused more severe wilt symptoms, as shown by real-time RT-PCR. Previously, the gene expression patterns of several virulence factors were analyzed and compared in the interaction of two F. oxysporum $\mathrm{f}$. sp. phaseoli strains displaying clear differences in virulence with a susceptible common bean cultivar (Niño-Sánchez et al. 2015). Interestingly, the genes encoding $f t f 1$, Six 1 , and Six 6 were only upregulated at an enhanced level in the highly virulent strain in root, crown, and hypocotyl tissue, matching with the beginning of massive colonization observed for this strain (Niño-Sánchez et al. 2015). Further studies on the expression of Six6 gene in planta during infection and gene knock-out experiments may be required to help elucidate its role in pathogenicity.

Our results suggest the suitability of the Six 6 gene as a possible locus for pathogenicity-based molecular diagnostics across the various formae speciales, indicating that this gene may be dispersed more broadly across the FOSC as a whole. Nevertheless, future work should include experiments aimed at functional characterization of the Six 6 gene within F. oxysporum isolates and identification of the target site and interactions with affected hosts to elucidate how this effector contributes to virulence of $F$. oxysporum isolates for hosts such as soybean and common bean.

\section{ACKNOWLEDGMENTS}

This project was funded by the Iowa Soybean Association. We thank D. Cruz and D. Mayfield for technical assistance and cooperation in this study and A. Kriss for her assistance with the statistical analysis.

\section{LITERATURE CITED}

Abo, K., Klein, K. K., Edel-Hermann, V., Gautheron, N., Dossahoua, T., and Steinberg, C. 2005. High genetic diversity among strains of Fusarium oxysporum f. sp. vasinfectum from cotton in Ivory Coast. Phytopathology 95:1391-1396.

Alves-Santos, F. M., Benito, E. P., Eslava, A. P., and Díaz-Mínguez, J. M. 1999. Genetic diversity of Fusarium oxysporum strains from common bean fields in Spain. Appl. Environ. Microbiol. 65:3335-3340.

Baayen, R. P., O’Donnell, K., Bonants, P. J. M., Cigelnik, E., Kroon, L. P. N. M., Roebroeck, E. J. A., and Waalwijk, C. 2000. Gene genealogies and AFLP analyses in the Fusarium oxysporum complex identify monophyletic and non-monophyletic formae speciales causing wilt and rot disease. Phytopathology 90:891-900.

Chakrabarti, A., Rep, M., Wang, B., Ashton, A., Dodds, P., and Ellis, J. 2011. Variation in potential effector genes distinguishing Australian and nonAustralian isolates of the cotton wilt pathogen Fusarium oxysporum f. sp. vasinfectum. Plant Pathol. 60:232-243.

Covey, P. A., Kuwitzky, B., Hanson, M., and Webb, K. M. 2014. Multilocus analysis using putative fungal effectors to describe a population of Fusarium oxysporum from sugar beet. Phytopathology 104:886-896.

Cruz, D., Ellis, M. L., Leandro, L. F., and Munkvold, G. P. 2013. Characterization of the interaction between soybean cultivars and isolates of Fusarium oxysporum causing seedling disease. (Abstr.) Phytopathology 103: $\mathrm{S} 2.31$.

de Sousa, M. V., Machado, J. C., Simmons, H. E., and Munkvold, G. P. 2015. Real-time quantitative PCR assays for the rapid detection and quantification of Fusarium oxysporum f. sp. phaseoli in Phaseolus vulgaris (common bean) seeds. Plant Pathol. 64:478-488.

de Vega-Bartol, J. J., Martín-Dominguez, R., Ramos, B., García-Sánchez, M. A., and Díaz-Mínguez, J. M. 2011. New Virulence Groups in Fusarium oxysporum f. sp. phaseoli: The expression of the gene coding for the transcription factor $f t f 1$ correlates with virulence. Phytopathology 101:470479.

Díaz Arias, M. M., Leandro, L. F., and Munkvold, G. P. 2013a. Aggressiveness of Fusarium species and impact of root infection on growth and yield of soybeans. Phytopathology 103:822-832.

Díaz Arias, M. M., Munkvold, G. P., Ellis, M. L., and Leandro, L. F. S. 2013b. Distribution and frequency of Fusarium species associated with soybean roots in Iowa. Plant Dis. 97:1557-1562.

Di Pietro, A., Madrid, M. P., Caracuel, Z., Delgado-Jarana, J., and Roncero, M. I. G. 2003. Fusarium oxysporum: Exploring the molecular arsenal of a vascular wilt fungus. Mol. Plant Pathol. 4:315-325.

Dodds, P. N., and Rathjen, J. P. 2010. Plant immunity: Towards an integrated view of plant-pathogen interactions. Nat. Rev. Genet. 11:539-548.

Ellis, M. L., Cruz, D., Leandro, L. F., and Munkvold, G. P. 2014. Genotypic and phenotypic characterization of fungi in the Fusarium oxysporum species complex from soybean roots. Phytopathology 104:1329-1339.

Ellis, M. L., Lanubile, A., Garcia, C., and Munkvold, G. P. 2016. Association of putative fungal effectors in Fusarium oxysporum with wilt symptoms in soybean. Phytopathology 106:762-773. 
Felsenstein, J. 1985. Confidence limits on phylogenies: An approach using the bootstrap. Evolution 6:227-242.

Fourie, G., Steenkamp, E. T., Ploetz, R. C., Gordon, T. R., and Viljoen, A. 2011. Current status of the taxonomic position of Fusarium oxysporum forma specialis cubense within the Fusarium oxysporum complex. Infect. Genet. Evol. 11:533-542.

Gawehns, F., Houterman, P. M., Ichou, F. A., Michielse, C. B., Hijdra, M., Cornelissen, B. J. C., Rep, M., and Takken, F. L. W. 2014. The Fusarium oxysporum effector Six6 contributes to virulence and suppresses I-2mediated cell death. Mol. Plant-Microbe Interact. 27:336-348.

Gordon, T. R., and Martyn, R. D. 1997. The evolutionary biology of Fusarium oxysporum. Annu. Rev. Phytopathol. 35:111-128.

Hartman, G. L., Huang, Y. H., Nelson, R. L., and Noel, G. R. 1997. Germplasm evaluation of Glycine max for resistance to Fusarium solani, the causal organism of sudden death syndrome. Plant Dis. 81:515-518.

Hogenhout, S. A., Van der Hoorn, R. A., Terauchi, R., and Kamoun, S. 2009. Emerging concepts in effector biology of plant-associated organisms. Mol. Plant-Microbe Interact. 22:115-122.

Houterman, P. M., Cornelissen, B. J., and Rep, M. 2008. Suppression of plant resistance gene-based immunity by a fungal effector. PLoS Pathog. 4: e1000061.

Houterman, P. M., Speijer, D., Dekker, H. L., De Koster, C. G., Cornelissen, B. J. C., and Rep, M. 2007. The mixed xylem sap proteome of Fusarium oxysporum-infected tomato plants. Mol. Plant Pathol. 8:215-221.

Huang, Y. H., and Hartman, G. L. 1998. Reaction of selected soybean genotypes to isolates of Fusarium solani f. sp. glycines and their culture filtrates. Plant Dis. 82:999-1002.

Huelsenbeck, J. P., and Ronquist, F. 2001. MRBAYES 3: Bayesian phylogenetic inference under mixed models. Bioinformatics 19:1572-1574.

Idnurm, A., and Howlett, B. J. 2001. Pathogenicity genes of phytopathogenic fungi. Mol. Plant Pathol. 2:241-255.

Killebrew, J. F., Roy, K. W., and Abney, T. S. 1993. Fusaria and other fungi on soybean seedlings and roots of older plants and interrelationships among fungi, symptoms, and soil characteristics. Can. J. Plant Pathol. 15:139-146.

Kimura, M. 1980. A simple method for estimating evolutionary rate of base substitutions through comparative studies of nucleotide sequences. J. Mol. Evol. 16:111-120.

Lanubile, A., Muppirala, U. K., Severin, A. J., Marocco, A., and Munkvold, G. P. 2015. Transcriptome profiling of soybean (Glycine max) roots challenged with pathogenic and non-pathogenic isolates of Fusarium oxysporum. BMC Genomics 16:1089.

Laurence, M. H., Burgess, L. W., Summerell, B. A., and Liew, E. C. Y. 2012. High levels of diversity in Fusarium oxysporum from not cultivated ecosystems in Australia. Fungal Biol. 116:289-297.

Laurence, M. H., Summerell, B. A., and Liew, E. C. Y. 2015. Fusarium oxysporum f. sp. canariensis: Evidence for horizontal gene transfer of putative pathogenicity genes. Plant Pathol. 64:1068-1075.

Lievens, B., Houterman, P. M., and Rep, M. 2009. Effector gene screening allows unambiguous identification of Fusarium oxysporum $\mathrm{f}$. sp. lycopersici races and discrimination from other formae speciales. FEMS Microbiol. Lett. 300:201-215.

Lievens, B., Rep, M., and Thomma, B. 2008. Recent developments in the molecular discrimination of formae speciales of Fusarium oxysporum. Pest Manage. Sci. 64:781-788.

Ma, L. J., van der Does, H. C., Borkovich, K. A., Coleman, J. J., Daboussi, M. J., Di Pietro, A., Dufresne, M., Freitag, M., Grabherr, M., Henrissat, B., Houterman, P. M., Kang, S., Shim, W. B., Woloshuk, C., Xie, X., Xu, J. R., Antoniw, J., Baker, S. E., Bluhm, B. H., Breakspear, A., Brown, D. W., Butchko, R. A., Chapman, S., Coulson, R., Coutinho, P. M., Danchin, E. G., Diener, A., Gale, L. R., Gardiner, D. M., Goff, S., Hammond-Kosack, K. E., Hilburn, K., Hua-Van, A., Jonkers, W., Kazan, K., Kodira, C. D., Koehrsen, M., Kumar, L., Lee, Y. H., Li, L., Manners, J. M., Miranda-Saavedra, D., Mukherjee, M., Park, G., Park, J., Park, S. Y., Proctor, R. H., Regev, A., Ruiz-Roldan, M. C., Sain, D., Sakthikumar, S., Sykes, S., Schwartz, D. C., Turgeon, B. G., Wapinski, I., Yoder, O., Young, S., Zeng, Q., Zhou, S., Galagan, J., Cuomo, C. A., Kistler, H. C., and Rep, M. 2010. Comparative genomics reveals mobile pathogenicity chromosomes in Fusarium. Nature 464:367-373.

Michielse, C. B., and Rep, M. 2009. Pathogen profile update: Fusarium oxysporum. Mol. Plant Pathol. 10:311-324.
Nei, M., and Kumar, S. 2000. Molecular Evolution and Phylogenetics. Oxford University Press, New York.

Niño-Sánchez, J., Tello, V., Casado-del Castillo, V., Thon, M. R., Benito, E. P., and Díaz-Mínguez, J. M. 2015. Gene expression patterns and dynamics of the colonization of common bean (Phaseolus vulgaris L.) by highly virulent and weakly virulent strains of Fusarium oxysporum. Front. Microbiol. 6:234.

O’Donnell, K. 1992. Ribosomal DNA internal transcribed spacers are highly divergent in the phytopathogenic ascomycete Fusarium sambucinum (Gibberella pulicaris). Curr. Genet. 22:213-220.

O'Donnell, K., Kistler, H. C., Cigelnik, E., and Ploetz, R. C. 1998. Multiple evolutionary origin of the fungus causing Panama disease of banana; concordant evidence from nuclear and mitochondrial gene genealogies. Proc. Natl. Acad. Sci. USA 95:2044-2049.

O’Donnell, K., Sutton, D. A., Rinaldi, M. G., Magnon, K. C., Cox, P. A., Revankar, S. G., Sanche, S., Geiser, D. M., Juba, J. H., van Burik, J.-A. H., Walsh, T. J., Francesconi, A., Anaissie, E. J., Padhye, A., and Robinson, J. S. 2004. Genetic diversity of human pathogenic members of the Fusarium oxysporum complex inferred from gene genealogies and AFLP analyses: Evidence for the recent dispersion of a geographically widespread clonal lineage and nosocomial origin. J. Clin. Microbiol. 42: 5109-5120.

Ramos, B., Alves-Santos, F. M., García-Sánchez, M. A., Martín-Rodrigues, N., Eslava, A. P., and Díaz-Mínguez, J. M. 2007. The gene coding for a new transcription factor (ftfl) of Fusarium oxysporum is only expressed during infection of common bean. Fungal Genet. Biol. 44:864-876.

Rep, M., and Kistler, H. C. 2010. The genomic organization of plant pathogenicity in Fusarium species. Curr. Opin. Plant Biol. 13:420-426.

Rep, M., Van Der Does, H. C., Meijer, M., van Wijk, R., Houterman, P. M., Dekker, H. L., de Koster, C. G., and Cornelissen, B. J. 2004. A small, cysteine-rich protein secreted by Fusarium oxysporum during colonization of xylem vessels is required for I-3-mediated resistance in tomato. Mol. Microbiol. 53:1373-1383.

Rizvi, S. A. A., and Yang, X. B. 1996. Fungi associated with soybean seedling disease in Iowa. Plant Dis. 80:57-60.

Schmittgen, T. D., and Livak, K. J. 2008. Analyzing real-time PCR data by the comparative $\left.\mathrm{C}_{\mathrm{T}}\right)$ method. Nat. Protoc. 3:1101-1108.

Schmidt, S. M., Houterman, P. M., Schreiver, I., Ma, L., Amyotte, S., Chellappan, B., Boeren, S., Takken, F. L. W., and Rep, M. 2013. MITEs in the promoters of effector genes allow prediction of novel virulence genes in Fusarium oxysporum. BMC Genomics 14:119.

Skovgaard, K., Nirenberg, H. I., O'Donnell, K., and Rosendahl, S. 2001. Evolution of Fusarium oxysporum f. sp. vasinfectum races inferred from multigene genealogies. Phytopathology 91:1231-1237.

Tamura, K. 1992. Estimation of the number of nucleotide substitutions when there are strong transition-transversion and $\mathrm{G}+\mathrm{C}$-content biases. Mol. Biol. Evol. 9:678-687.

Tamura, K., Stecher, G., Peterson, D., Filipski, A., and Kumar, S. 2013. MEGA6: Molecular Evolutionary Genetics Analysis Version 6.0. Mol. Biol. Evol. 30:2725-2729.

Thatcher, L. F., Gardiner, D. M., Kazan, K., and Manners, J. M. 2012. A highly conserved effector in Fusarium oxysporum is required for full virulence on Arabidopsis. Mol. Plant-Microbe Interact. 25:180-190.

Thompson, J. D., Higgins, D. G., and Gibson, T. J. 1994. CLUSTAL W: Improving the sensitivity of progressive multiple sequence alignment through sequence weighting, positions-specific gap penalties and weight matrix choice. Nucleic Acids Res. 22:4673-4680.

Van Der Does, H. C., Lievens, B., Claes, L., Houterman, P. M., Cornelissen, B. J., and Rep, M. 2008. The presence of a virulence locus discriminates Fusarium oxysporum isolates causing tomato wilt from other isolates. Environ. Microbiol. 10:1475-1485.

White, T. J., Bruns, T., Lee, S., and Taylor, J. 1990. Amplification and direct sequencing of fungal ribosomal RNA genes for phylogenetics. Pages 315-322 in: PCR Protocols: A Guide to Methods and Amplifications. M. A. Innis, D. H. Gelfand, J. J. Sninsky, and T. J. White, eds. Academic Press, Inc., San Diego, CA.

Zelaya-Molina, L. X., Ortega, M. A., and Dorrance, A. E. 2011. Easy and efficient protocol for oomycete DNA extraction suitable for population genetic analysis. Biotechnol. Lett. 33:715-720. 